\title{
SURINAME IN WILLOUGHBY'S TIJD
}

en

eenige merkwaardige verschijnselen met de negerslavernij annex

DOOR

W. R. MENKMAN

In den eersten jaargang van ons tijdschrift is indertijd een niet zeer geslaagde - vertaling verschenen van Mrs. Aphra Behn's beroemden laat-zeventiende-eeuwschen roman $\mathrm{The}$ royal S l a ve, een werk dat door ons in Nederland slechts geraadpleegd kan worden in $\mathrm{Th}$ e w o r k s of A p h r a B h n, van Montague Summers, London 1915.

Wijlen Dr. H. D. Benjamins liet aan deze vertaling voorafgaan eenige aanteekeningen betreffende de schrijfster, de eerste vrouw die door middel van litterarischen arbeid in haar onderhoud voorzag, althans in Engeland en volgens haar biographen. In den tweeden jaargang van De West-Indische Gids heeft Benjamins de vraag behandeld of het waarschijnlijk is dat Mrs. Behn nimmer in Suriname geweest is en haar roman dus geheel op fantasie zou berusten.

De Dictionary of $\mathrm{Nat}$ ional Biog raphy wordt niet genoemd, maar deze bevat toch ook tamelijk veel over deze merkwaardige schrijfster. Het vreemde dat men een barbier met een hooge functie in de koloniën bekleed zou hebben, wordt wellicht te niet gedaan door de stelling dat de man met wiens gezin Aphra zich naar West Indië begaf haar vader niet was; overigens kan haar wettelijke vader behalve barbier ook wel chirurgijn geweest zijn en kwam het destijds zeker niet minder vaak voor dan tegenwoordig, dat maatschappelijk hooger en lager geplaatste personen tot dezelfde familie behooren. Als weduwe - van een koopmah van Hollandsche afkomst - moet Aphra een relatieaangeknoopt hebben met een anderen Nederlander, een zekeren Van den Aalbert, die echter overleed voordat het tot een huwelijk was kunnen komen. 
Mrs. Behn's letterkundige arbeid wordt beschreven als aan den decadenten kant te zijn, wat overeenkwam met den geest des tijds; het schandaleuze en het erotische deden opgeld, vooral in tooneelwerken - en de schrijfster, die van haar pen moest leven, had natuurlijk rekening te houden met den smaak van haar publiek.

Om op Dr. Benjamins' commentaren terug te komen, deze hadden de groote verdienste van de aandacht te vestigen op de litteratuur over het Suriname van den eersten Engelschen tijd, d.w.z. van dien van vóór 1667 , welke omvangrijker is dan wel eens aangenomen werd. Willoughbyland, omvattend de rivieren Marowijne, Suriname, Saramacca en Coppename 1), was dan ook naar den maatstaf van destijds lang geen onbeteekenende tropische vestiging - en bij de geheime onderhandelingen van 1672 tusschen Prins Willem III en Koning Karel II 2 ) was haar wederafstand aan Engeland een der punten.

Inderdaad, er is veel dat er op wijst dat Aphra Behn, heel kort voor het uitbreken van den tweeden Engelschen oorlog, in Suriname vertoefd heeft - en wat zij mededeelt omtrent menschen en dingen in deze kolonie - afgezien dus van den Oroonoko-roman - verdient met andere gegevens vergeleken te worden.

Zóó b.v. de herhaalde mededeeling dat de Engelschen met de Indianen op vriendschappelijken voet trachtten te blijven, omdat deze inboorlingen de blanken verre in getalsterkte overtroffen. In Wolbers' Ge s chiedenis van Surina me lezen wij wel dat er in 1654 nog maar 350 Engelschen in de kolonie aanwezig waren, maar ook dat hun aantal toenam - en nadat in 1668 de Zeeuwen opnieuw de baas geworden waren trokken 1200 kolonisten weg naar Jamaica. Willoughby had zich in Engeland veel moeite gegeven om kolonisten naar zijn volkplanting te doen uittrekken, getuige zijn prospectus van 1655: „Certain overtures made by Lord Willoughby of Parham unto all such as shall incline to plant in ye colony of Saranam on ye continent of Guiana" 3). Men zal derhalve in Mrs. Behn's tijd wel over een flink aantal weerbare mannen beschikt hebben, maar de Indianen waren lastige elementen, als tegenstanders eener verspreid wonende

1) Vincent T. Harlow, Colonising expeditions to the West Indies and Guiana 1623-1667, Hakluyt Society second series LVI 1924.

$\left.{ }^{2}\right)$ R. Fruin, Willem III en zijn geheime onderhandelingen met Karel II in 1672 (Bijdr. Vad. Gesch. en Oudheidk. II, 3).

3) Sloane M. S. S. 159 fol. 20-21b, in the Br. Museum, opgenomen door Vincent T. Harlow, zie boven. 
blanke gemeenschap, welke geheel door het plantagebedrijf in beslag genomen werd. Indiaansche slaven hadden de Engelschen in Suriname blijkbaar ook reeds, maar zij zouden het niet gewaagd hebben vrije Indianen tot slaven te maken; toch ontstond er op een oogenblik twist met de Indianen, welke echter wel niet door een in slavernij levenden Afrikaanschen ,,prins” bijgelegd zal zijn.

In het algemeen komt hetgeen Aphra Behn mededeelt omtrent de verhouding tusschen Europeanen en autochthonen overeen met wat wij weten van die verhouding - in de Guyanas en op de Caraibische eilanden - onder Engelsche, Fransche en Nederlandsche vlag - in denzelfden, in vroeger en in later tijd. Dat de Surinaamsche Indianen wel niet zullen gewoond hebben in wat wij ,,steden" zouden noemen, ligt voor de hand; dat zij rouwden over den dood van den Engelschen gouverneur werpt Dr. Benjamin's veronderstelling omver als zou Mrs. Behn in 1664 in Suriname vertoefd hebben, want Francis Lord Willoughby of Parham kwam in 1666 om het leven.

Wat betreft de aankomst van Oroonoko in de kolonie valt nog op te merken dat er in Januari 1663 een slavenschip van de kust van Guiné in Suriname arriveerde, met slechts 130 koppen, want men had er op de reis 54 verloren ${ }^{1}$ ).

Merkwaardig is het verhaal van de vreemde Indianen van ongewone gestalte, die stofgoud uit het Zuiden medebrachten en zich bedienden van een koord met knoopen, als middel om een getal te onthouden (de Peruviaansche „quipu”?). Immers, er zijn ettelijke malen berichten opgedoken betreffende Indianen uit het Inca-rijk, die om aan de Spanjaarden te ontkomen zich naar de Guyanas in het Oosten begaven 2). Van het instellen, door den Engelschen gouverneur van Suriname, eener wacht aan de monding der Amazonerivier, ten einde den toegang tot de vindplaatsen van het goud te versperren, is, naar ik meen, in de geschiedenis niets te vinden. In ieder geval waren de dagen der Engelsche, Iersche en Nederlandsche vestigingen in de Amazonedelta al lang voorbij en behoorde de macht onzer West-Indische Compagnie in Brazilië tot het verleden; dit deel van Zuid Amerika was onbetwist Portugeesch gebied.

Aphra Behn noemt de schortjes, door de Indianen gedragen „,comitias” en spreekt van een Indiaanschen bezweerder als van

1) Brief William Yearworth, opgenomen onder No. VI (documenten paragr. V) in Harlows Colonising expeditions, zie vroeger.

2) De West-Indische Gids VII p. 31 en XII p. 353. 
een „peeie”; Dr. Benjamins gebruikt de woorden „kwejoe” (kamiesa, uit het Port., lendedoek der mannen, kwejoe, Car., schortje der vrouwen) en ,piaiman (puyai, Car.); overigens wist laatstgenoemde met de in den roman voorkomende Indiaansche woorden en uitdrukkingen geen raad. Het zou wellicht de moeite waard zijn dat een specialist er zich toe zette in deze eenig licht te ontsteken.

De weinige door de schrijfster gegeven plaatsnamen heeft Benjamins met oude kaarten vergeleken en thuis kunnen brengen. Er waren blijkbaar destijds in Suriname slechts drie vestigingen, t.w. Thorarica, Saint Johns en Parham, zie den brief van William Byam van 15 Augustus 1664 1). Parham was, volgens de op last van Abraham Crijnssen verrichte inventarisatie, een ,plantagie toebehoord hebbende aen Milordt Willoughby, staende in de oplantsche divisie". De eigendommen der niet aanwezige Engelschen werden in 1667 ten bate der Staten van Zeeland verbeurd verklaard en de Zeeuwsche commandeur stelde over Willoughby's Parham een beheerder aan 2). Ter hoofdplaats Thorarica werd op 6 Maart aan boord van de „Zeelandia” het verdrag gesloten tusschen de Zeeuwen en de Engelschen ${ }^{3}$ ).

De Encyclopaedie van Ned. West-Indië geeft inlichtingen aangaande Parham House, het gouvernements gebouw in Thorarica, gelegen in het kerspel Saint Bridget - en het oude blokhuis van 1630 .

Dr. Benjamins heeft zich ook verdiept in de vraag over welke gewapende macht in Willoughby's kolonie beschikt kon worden. Men had door een epidemie veel volk verloren, toen in 1667 de vijand verscheen; in het fort aan de Surinamerivier lagen honderd Europeanen en zestig met pieken gewapende negers 4). Dat die Europeanen militairen waren, kan hieruit blijken, dat na de capitulatie van 17 Februari verscheidene manschappen naar den vijand overliepen ${ }^{5}$ ); de in de koloniën dienende beroeps-soldaten van dien tijd hadden in dit opzicht weinig scrupules. Ook bij de Engelschen echter waren de vrije burgers verplicht de wapenen

1) Harlow, Colonising expeditions, doc. paragr. V no. VI, zie vroeger.

2) J. C. M. Warnsinck, Abraham Crijnssen, Amsterdam 1936, bijl. E, bl. 145-146.

3) Als boven, bl. 27, noot, verw. n. Bijdr. en Meded. Hist. Gen. 39 ste dl. bl. 196.

4) Warnsinck, Abraham Crijnssen, zie boven, bl. 25.

s) Harlow, Col. exp., zie boven, doc. paragr. V, no. VIII. 
te dragen, ter verdediging - en Ds. S. V. Westhuysen schreef in zijn „Verhael" dat ,,seeker secours van 600 man”, indien op tijd in het „,casteel” aangekomen, het den onzen nog lastig genoeg had kunnen maken 1); blijkbaar was hier sprake van de gewapende burgerij uit de districten. Dat deze burgers in Oroonoko's tijd slecht gewapend waren is wel mogelijk, maar zij zullen ,op expeditie tegen gedeserteerde slaven, hun zweepen wel niet als wapenen hebben medegenomen; overigens was de „,cat-o'-nine tails" geen slavenzweep, maar een strafwerktuig bij de marine.

$\mathrm{Er}$ is m.i. geen goede reden voor twijfel aan het bestaan van boschneger-vestigingen in Suriname, reeds vóór 1667; zelfs zijn er eenige bijzonderheden dienaangaande bekend 2 ), zoodat ook een tocht tegen hen, naar het binnenland, tijdens het verblijf van Aphra Behn plaats kan hebben gehad. Zoo lang de blanken in tropische gewesten negerslaven gehouden hebben, dat is dus sedert vroeg in de zestiende eeuw, hebben zich, wanneer de omgeving er de mogelijkheid toe bood, deserteurs in de wildernis gevestigd en zijn zij een gevaar geweest voor de Europeesche kolonisten. Wanneer werkelijk de boschnegers met wie Van Aerssen van Sommelsdijk vrede sloot, de afstammelingen waren van wegloopers uit den Engelschen tijd 3), dan was het euvel der marons ook in Suriname kort na het invoeren van Afrikaansche slaven ontstaan, evenals elders.

De binnenlandsche wildernis was overigens ook bij de blanken niet onbekend; reeds van heel vroeg in de zeventiende eeuw hadden de factors der Zeeuwsche en Hollandsche kooplieden groote reizen in het rivierengebied der Guyanas gemaakt, voor den handel met de Indianen - en nog in de achttiende eeuw genoten de Surinaamsche gouverneurs inkomsten uit dien handel, door z.g. ,,bokkenruilders" uitgeoefend 4). Ook in de meer westelijke Nederlandsche Guyanas had ruilverkeer in het binnenland plaats, door de z.g. ,,zwervers”, reizende kooplieden, die langdurige en verre tochten ondernamen ${ }^{5}$ ). Helaas waren de ruilgoederen der Indianen maar al te vaak slaven, d.w.z. krijgsgevangenen die aan de blanken verkocht werden. Opmerkelijk is het dat Aphra Behn

1) Warnsinck, zie voren, bijl. C, bl. Z 3.

2) J. J. Hartsinck, Beschrijving van Guiana of de Wilde Kust, in Zuid-Amerika, Amsterdam 1770, II bl. 755.

3) J. Wolbers, Geschiedenis van Suriname, bl. 64 .

4) Als boven, bl. 217, 218, 284.

s) J. A. J. de Villiers, Storm van 's-Gravesande, zijn werk en zijn leven, 's-Gravenhage 1920. 
op een harer tochten een ,Indiaansch koopman” ontmoet, blijkbaar een blanke, die er zijn werk van maakte de Indianenstammen te bezoeken welke zelf niet gaarne naar de nederzettingen der blanken reisden.

Dr. Benjamins was, terecht, van oordeel dat ook een halve eeuw na dato bij de Europeanen in de Guyanas de herinnering aan El Dorado nog levendig was. Werd niet zelfs in den tijd van Van Aerssen van Sommelsdijk nog een expeditie uitgerust ter op- · sporing van het meer Parima? 1).

In de artt. 6 en 8 der capitulatie van 6 Maart 1667 werd de Indiaansche handel geregeld, welke dus een bestaand instituut was; in art. 11 werd bepaald dat de Caraibische ,naburen" goed behandeld dienden te worden en beschermd tegen andere stammen niet alleen, maar ook tegen de Nederlanders en de Franschen (handelaars?), die met hen in aanraking kwamen 2).

Met hetgeen er in den roman voorkomt aangaande Surinaamsche fauna en flora heeft Benjamins afgerekend. De armadillo is natuurlijk de kapassi, reusachtige tijgers, die zelfs ossen verslinden, komen in het land niet voor, al is de jaguar dan ook een roover van klein vee (ook een plantagekoe wordt wel eens door hem verslonden) ${ }^{3}$ ) en soms voor den mensch niet geheel ongevaarlijk. De mededeeling aangaande Alexander, die groote slangen tegenkwam aan de Amazone, is raadselachtig. Sarumboblad heb ik niet terug kunnen vinden; wellicht werd bedoeld simarubablad.

Ook enkele met de slavernij in verband staande vreemde woorden zijn niet moeilijk thuis te brengen. Pickaninies (piccaninnies) zijn kleine kinderen en het woord is van het Portugeesch afkomstig (pequeno, pequena = klein), backearary is backra, de algemeene naam voor den blanke 4 ). Dit laatste woord schijnt van Afrikaansche herkomst (kust van Calabar) te zijn en groot of machtig man, dan wel demon, te beteekenen; het werd ook in Noord Amerika gebruikt, althans ik trof het aan in een aldaar spelenden Duitschen roman, in de vormen Buckramann en Buckra ${ }^{5}$ ). Osnabruch is niet een soort Hollandsche kleedij, maar een stof, genoemd naar de industriestad Osnabrück, welke gedurende een paar eeuwen gediend heeft voor de kleeding der negerslaven;

1) Hartsinck, Beschrijving, zie vroeger, II, bl. 650 .

2) Encyclopaedie van Ned. West-Indië, 434

3) Jhr. Mr. W. Elout van Soeterwoude, Onze West, 's-Gravenhage 1884 .

4) Webster's New International Dictionary.

s) Fried. Gerstäcker, Die Flusspiraten des Mississippi, I, bl. 127, 241. 
de Nederlanders waren de groote importeurs van Duitsche goederen in de Westindische slavenkoloniën, ook in die onder vreemde vlaggen.

Interessant is wat Aphra Behn vertelt over de blanken en hun levenswijze in Willoughbyland. Wij kunnen ons levendig voorstellen dat het daar een vrijgevochten samenleving was, evenals later onder Zeeuwsch en Amsterdamsch bewind. Drankzucht en tuchteloosheid waren ook de euvels waar Van Aerssen van Sommelsdijk over klaagde; zoowel onder de Nederlandsche als onder de Engelsche vlag herbergden de Westindische koloniën maar al te veel personen die om minder fraaie redenen het moederland verlaten hadden. Van Aerssen had groote moeite, eenigszins geschikte raadsleden te vinden; nog in de eerste helft der achttiende eeuw echter slaagden de gouverneurs der Engelsche „provinces” in Amerika er niet altijd in twaalftallen inwoners aan de moederlandsche Board of Trade te kunnen aanbevelen, ter vervulling van toekomstige vacatures in de plaatselijk ,,councils" ${ }^{1}$ ).

Het waren blijkbaar niet de gunstigste elementen der Angelsaksische samenleveng, die na de Zeeuwsche verovering Suriname verlieten, om zich o.a. op Jamaica neer te zetten, waar het blanke inwonertal versterking noodig had; toch zullen er ook wel achtenswaardige Engelschen in de kolonie geleefd hebben en wellicht gebleven zijn. Desniettemin kan het juist geweest zijn wat Mrs. Behn schreef, dat zij, ongeveer vijf en twintig jaar na haar bezoek aan Suriname, zich niemand meer herinnerde die in staat geweest zou zijn in haar plaats het Engelsche publiek op intelligente wijze over de toestanden in de kolonie in te lichten.

Enkele historische figuren in Willoughbyland komen in $\mathrm{T} \mathrm{h}$ e $\mathrm{R}$ o y a l S la ve voor. In de eerste plaats moge er op gewezen worden dat het volstrekt niet onwaarschijnlijk is dat de vader der schrijfster, of de man dien zij in haar werk haar vader noemt, ware hij niet op reis overleden, het bestuur zou hebben gevoerd over zes en dertig eilanden, benevens het continentale Suriname. Barbados - en het onderhoorige Antigua - hadden den uitgeweken Karel II als Koning erkend en na de restauratie werd Willoughby niet alleen opnieuw begiftigd met Suriname (te zamen met Laurens Hyde, een aangetrouwde relatie van den Koning), maar ook benoemd tot gouverneur van de eilanden, behoorende tot het Carlislepatent van 1627 - en dat waren er heel wat - voor de rest van den tijd waarvoor hij die eilanden in 1647 van den ,,pat-

1) Leonard Wood Labarie, Royal government in America, Yale University Studies 1930, Ch. I. 
entee" in huur gekregen had. Willoughby had in 1650 Barbados bezocht, met een door Karel II in zijn ballingschap gecontrasigneerde commissie - en de gouverneur was toen op genoemd eiland in zijn rechten erkend. Aldaar en op Antigua verkreeg Willoughby ook particuliere eigendommen ${ }^{1}$ ). Zich niet in zijn bestuursgebied willende vestigen echter zal hij, naar de Engelsche gewoonte van dien tijd, een ,,deputy" benoemd hebben; of deze laatste inderdaad den titel voerde van luitenant-generaal is van weinig belang.

De bekendste figuur onder de door Aphra Behn genoemde historische personen is William Byam, dien zij blijkbaar al heel slecht gezind was. Er bestaat over hem tamelijk veel litteratuur.

Ten tijde der executie van Karel I was op Barbados de majoor Byam een der voornaamste vertegenwoordigers van het royalisme; de invloed zijner geestverwanten had hem de positie bezorgd van ,"treasurer and master of the defences". Hij en Thomas Modyford, de latere gouverneur van Jamaica, werden verantwoordelijk gehouden voor de vexaties waaraan de independenten op Barbados blootstonden, doch Byam was de militantste van de twee. Een ander Barbadiaansch royalist, Antony Rowse (Rouse), verhuisde in 1650 met 300 anderen naar Suriname; deze expeditie had den steun van den juist uit Europa aangekomen Willoughby, die, zooals wij gezien hebben, den houder van het Carlisle-patent en tevens den in Nederland vertoevenden kroonpretendent vertegenwoordigde. $\mathrm{Na}$ de onderwerping van Barbados, in 1652, aan het gezag van Cromwells' parlement, werd Byam van het eiland gebannen en twee jaar later vinden wij hem in Suriname terug, als opvolger van Rowse in de leiding der vestiging aldaar. Deze nederzetting, door Willoughby aan zich zelf overgelaten, wist zich, gebruik makend van de verwarring in het moederland tijdens den burgeroorlog, een soort onafhankelijkheid te verwerven, zooals ook in andere Engelsche koloniën van dien tijd geschiedde. De inwoners kozen gedelegeerden, die een bestuursregeling vaststelden; de verschillende districten zouden bij meerderheid van stemmen gedeputeerden aanwijzen, die telkens voor een jaar het bewind zouden voeren, met onderwerping aan de wetten en aan de oppermacht van het moederland. Uit hun midden wezen gedeputeerden een president aan, met het uitvoerend gezag bekleed. Byam wist zich een meerderheid te verschaffen in het college, dat hem drie maal achtereen tot president benoemde

1) James A. Williamson, The Caribbees under the proprietary patents, London 1926. 
(1654-1657); Willoughby werd door Cromwell in zijn rechten op Suriname erkend, maar bleef in Engeland vertoeven - en Byam trad als ,,deputy governor” op, welke functie hij bleef bekleeden onder het patent van 1663, waarbij de eigendom der kolonie verdeeld werd tusschen Lord Francis W. en Clarendon's zoon. Benjamins heeft een memorie van Byam aangehaald van 1661, betreffende de politieke moeilijkheden in Suriname en sprak ook over den luitenant-kolonel Robert San(d)ford, een lid der zich verdrukt achtende minderheid in de kolonie, welke officier in 1662 een beroep deed op de Privy Council in Engeland 1).

In de jaren welke aan het feitelijke uitbreken van onzen tweeden Engelschen oorlog voorafgingen was Frankrijk voor beide partijen een dubieuze politieke factor; volgens het verdrag van 1662 was Lodewijk XIV verplicht de Republiek bij te staan, wanneer zij in Europa zou worden aangevallen, maar eerst in 1666 koos de Koning openlijk voor Nederland partij. Byam ontving aanvankelijk van de Fransche gouverneurs van Cayenne en Sinamary vriendschappelijke brieven, maar hij antwoordde dat hij geen neutraliteit in acht zou kunnen nemen, hoewel bij de vroegere gelegenheid op de Leeward Islands Engelschen en Franschen goede vrienden gebleven waren, ondanks den oorlog tusschen de moederlanden. Waren dus blijkbaar de oostelijke buren niet zeer betrouwbaar te achten, uit het Westen dreigde voor Willoughbyland het gevaar van een inval uit het Nederlandsche Berbice, waar de commandeur Matthijs Bergenaer over de diensten van Indiaansche bondgenooten kon beschikken. Politiek waren de Surinaamsche inwoners verdeeld - op Willoughby, die in 1665 in de kolonie vertoefde, werd door een der malcontenten een aanslag gepleegd - en militair was men minder goed voorbereid; de bouw van het fort aan de Surinamerivier was vertraagd, ook door het uitbreken eener epidemische ziekte te Thorarica, welke zich snel verbreidde - en Willoughbyschans was dan ook niet gereed, toen Crijnssen verscheen, terwijl het kleine garnizoen, zooals wij gezien hebben, weinig betrouwbaar was. Byam capituleerde op de best bedingbare voorwaarden en de Zeeuwsche vlootvoogd van zijn kant toonde zich zoo tegemoetkomend als mogelijk was, vooral bij het sluiten van het latere verdrag te Thorarica. Direct nadat in het najaar van 1667 Suriname in handen gevallen was van Henry Willoughby - den zoon van William, broeder en op-

1) Harlow, Col. exp., zie vroeger, hoofdst. Barbados en Guiana, doc. paragr. V; Williamson, The Caribbees u. th. proprietary patents, zie vroeger. 
volger van den in 1666 omgekomen Francis - en den vice admiraal Sir John Harman, werd krijgsraad gehouden over Byam, die van lafhartigheid beschuldigd was, o.a. door zijn ouden vijand Robert Sanford, maar vrijgesproken werd. Zooals bekend is werd de z.g. herovering, feitelijk een vrijbuiters-onderneming, niet erkend en Suriname bleef Zeeuwsch; onder de auspiciën van Lord William Willoughby verhuisden een aantal Engelsche kolonisten naar Antigua, welk eiland sedert tot bloei gekomen is. Tot deze uitgewekenen behoorde ook Byam, die later het eiland Antigua als gouverneur bestuurd heeft; hij schreef het verhaal van het verlies van Suriname (Sloane M.S.S. 3662) en er is een brief van hem bewaard gebleven van 1670 aan Lord Willoughby, waarin hij bericht gaf van een overval op het destijds Nederlandsche Tobago, door Indianen van andere eilanden 1).

Een autoriteit over wien Mrs. Behn evenmin te spreken was als over Byam, was James Banister, (sergeant) majoor en raadslid, dien Henry Willoughby, bij zijn aftocht in Februari 1668, als commandant van het fort en gouverneur der kolonie achterliet en die door Crijnssen, na diens terugkomst, in Augustus van dat jaar, gevangen genomen en naar Zeeland opgezonden werd 2).

Verder treffen wij in Benjamins' toelichtingen nog aan Sir Robert Harley Knt (geb. 1626, overl. 1673), een ouden vriend van Francis Willoughby; hij had plantage-belangen in Suriname en was de zoon van den gelijknamigen ,,master of the Mint" in Engeland ${ }^{3}$ ).

Eindelijk wordt door Aphra Behn nog genoemd John Treffrey, in een acte van 1 April 1667 door de Zeeuwen als ,,Secretaris van de Provintie" aangeduid ${ }^{4}$ ).

$\mathrm{Al}$ dan niet - maar zeer waarschijnlijk wèl - op grond van eigen waarneming, heeft Mrs. Behn ons het Suriname beschreven van kort voor den tweeden Hollandsch-Engelschen oorlog; hetgeen niet zeggen wil dat zij overal een juist beeld gaf van menschen en toestanden. Speciaal met betrekking tot de verhouding tot de

1) Williamson, The Caribbees u. th. prop. patents, zie vroeger; Harlow, Col. exp., zie vroeger, hoofdst. Barbados, hoofdst. Guiana, doc. paragr. V.; Warnsinck, Abraham Crijnssen, zie vroeger; Wolbers, Gesch. v. Suriname, zie vroeger; N. Japikse, De verwikkelingen tusschen de Republiek en Engeland van 1660-1665, diss. 1900; Calendar of State Papers, America \& West Indies, 1669-1674, No. 508, bl. 205.

2) Warnsinck, Abraham Crijnssen, zie boven.

3) Harlow, Col. exp., zie boven, doc. paragr. V., Nos. VI en VII; Dictionary of National Biography.

4) Warnsinck, Abraham Crijnssen, zie boven. 
slaven kan men het Oroonoko- verhaal wat men noemt „,voelen en tasten"; voor ridderlijke gedragingen over en weer was geen plaats en een blanke zuchtte niet om de liefde eener slavin. Ook lijkt het niet juist dat men gewoon was den slaven Europeesche namen te geven; tot in den tegenwoordigen tijd zijn onder de Surinaamsche volksklasse ettelijke Afrikaansche voornamen in gebruik gebleven, als overblijfsel uit den slaventijd. Het afgrijzelijke verhaal eener strafoefening, aan een slaaf voltrokken, dat de schrijfster ten beste gaf, behoeft geen verzinsel te zijn; in Europa waren wellicht executies als die van Balthazar Gerards en Ravaillac uit de mode geraakt, maar de geest welke dergelijke barbaarschheden uitgedacht had kon nog niet dood zijn. Intusschen is het zeker een verschijnsel dat de aandacht verdient, dat een Europeesche vrouw in het laatste kwartaal der zeventiende eeuw een boek uitgaf waarin wel niet tegen de slavernij als zoodanig gepleit, maar toch van afkeer blijk gegeven werd voor de onmenschelijkheden waartoe zij leiden kon. Al gaf dan ook Aphra Behn een met naïeve voorstellingen opgesmukt, als onwezenlijk aandoend verhaal. Dit laatste deed H. Beecher Stowe, wier U n c l e Tom's C a bin twee eeuwen later speelde, eveneens, zij het met een ernstiger doel voor oogen.

Vergelijken wij de werken dezer twee schrijfsters, dan treft het ons, dat van de religieuze tendentiën, in dat der laatstgenoemde sterk uitkomend, in dat van de eerste zooveel minder te bespeuren valt; waarom Aphra Behn, die toch wel geen Roomschkatholieke neigingen gehad zal hebben, haar zwarte beschermelingen o.a. met verhalen over nonnen trachtte te stichten, is niet duidelijk. Misschien echter had zij zoodanige neigingen ook wèl, doch dat blijkt overigens niet.

Heeft Harriet voor haar hoofdfiguur een neger tot voorbeeld gekozen die zijn medeslaven tot een godsdienstig leven opwekte - en die later in Canada als negerpredikant is opgetreden -, Aphra kan in Suriname een Afrikaanschen slaaf hebben opgemerkt, wiens houding en gedragingen haar later tot haar roman geïnspireerd zouden hebben. Benjamins heeft de aandacht gevestigd op mededeelingen van Herlein en Teenstra, betreffende de pretensies van slaven in West Indië, die van voorname Afrikaansche afkomst zouden zijn geweest; zoodanige verhalen zijn ook tot ons gekomen door de zeventiende-eeuwsche geschriften van Jean Barbot en Père Du Tertre 1).

1) Medeged. d. Lucien Peytraud, L'esclavage aux Antilles françaises avant 1789, Paris 1897, p. 94, 95. 
Dat het gedeelte van The Royal Slave dat in Afrika speelt geheel op fantasie berust, kunnen wij wel met gerustheid aannemen, op grond van hetgeen talrijke Europeesche reizigers, die in de zeventiende eeuw de Westkust bezocht hebben, ons over de menschen en toestanden aldaar verteld hebben. Men deed daar niet aan sentimenteele liefde, had geen huwelijksceremonieel met sluiers en hield er geen vrouwenpaleizen op na; ook logeerden de opperhoofden, op het oorlogspad zijnde, niet in tenten. Dat slavenhalers zich door list of geweld van negers meester maakten, was niets ongewoons, althans bij de Engelsche slavenhalers, maar dat een Europeaan (de Franschman uit het verhaal) slachtoffer van deze soort menschenroof zou zijn geworden, lijkt niet wel denkbaar. Aan den anderen kant echter is het juist dat de neger,koningen" die met de blanken in aanraking kwamen, nieuwsgierigheid aan den dag legden naar Europeesche aangelegenheden en dat soms aan de Westkust inboorlingen niet alleen Portugeesch, maar ook wel wat Engelsch of Fransch machtig waren.

Oroonoko verkocht slaven aan de blanken, wat ook al weder niet met de toenmalige toestanden in West Afrika in strijd is; zijn koopers echter zullen wel geen Spanjaarden geweest zijn. Dezen waren niet gewoon zelf de slavenvaart uit te oefenen; zij waren tot 1640 door de Portugeezen bediend en daarna door sluikhandelaars van verscheiden nationaliteiten. In den tijd waarin Mrs. Behn haar roman laat spelen was er juist een nieuw ,asiento" gesloten door de Spaansche kroon, dat van 5 Juli 1662, geldig van 1 Mei 1663, met Domingo Grillo en Ambrosio Lomelino. Ook echter waren de Engelschen actief geworden; de Engelsche Afrikacompagnie van 1618 verkreeg in 1660 een nieuw patent en werd Royal Africa Company, onder bescherming van den Hertog van York, den lateren Koning Jacobus II 1). Men zal derhalve in Cormantin, waar de koninklijke slaaf vandaan kwam, wel niet veel gelegenheid gehad hebben de Spaansche taal te leeren.

Cormantijn-negers waren, vooral bij de Engelschen, gezocht en werden door hen gewaardeerd, als goede werkkrachten, doch zij waren weinig handelbaar. Of het negertype van Oroonoko inderdaad dat der Cormantijners was, zou ik niet vermogen uit te maken; nog in onzen tijd echter kwamen onder de Surinaamsche ,,inboorlingen" menschen voor met gitzwarte huidkleur, meer

1) Documents Illustrative to the Hist. of the Slave Trade to America ed. by Elis. Donnan. Publ. by the Carnegie Inst. of Washington, Vol. II, sevent. century, introduction. 
golvend dan kroeshaar, een fijne neus en parelmoerwitte tanden. Aphra Behn kan zich een kwart eeuw na dato heel goed zulk een „mooien" neger herinnerd hebben.

Vreemd echter doen haar Afrikaansche eigennamen aan (Oroonoko, Imoinda, Aboan, Tuscan, Onahan, Jamoan) en het woord „otan" voor vrouwenverblijf ben ik in de Afrika-litteratuur niet tegengekomen tot dusver. Wel lijkt het verantwoord dat Oroonoko en de zijnen getatoueerd waren; onze eigen oude schrijvers over West Afrika spreken herhaaldelijk over inboorlingen die ,"gepickeert” waren (Port. picar, door de onzen verbasterd tot peckeren of pikkelen) 1). Aphra Behn vergelijkt de tatouage met die der oude Picten, praehistorische bewoners der Britsche eilanden, waarschijnlijk van Iberisch ras, ongeveer in de negende eeuw met de Schotten samengesmolten ${ }^{2}$ ).

Ten slotte de mogelijkheid dat op onrechtmatige wijze verkregen slaven in West Indië aangevoerd werden. Evenals iedere andere handel had ook de menschenhandel zijn ethiek, welke medebracht dat uit Afrika slechts weggevoerd werden die negers welke volgens de gebruiken des lands aldaar als slaven golden en op regelmatige wijze van de inlandsche handelaren gekocht waren. Dat deze ongeschreven wet door de Europeanen niet altijd nagekomen werd echter, is maar al te waar. Afgezien nog van aperten menschenroof, om zich zonder betaling van slaven meester te maken, kwam ook een andere misstand voor, verband houdend met het Afrikaansche gebruik dat voor een schuld een persoon in pandelingschap genomen kon worden, welke persoon niet de debiteur zelf behoefde te zijn. Niet alleen dat de slavenhaler soms trachtte den inlandschen handelaar te bedriegen, maar hij werd ook zelf wel eens bedrogen en stelde zich dan schadeloos door tot de tegenpartij in betrekking staande personen aan boord vast te houden, eventueel als slaven mede te nemen. En eindelijk waren de verkoopers aan de kust niet beter dan de Europeesche koopers; in den aanvang der achtiende eeuw kwam het nog voor dat te Accra Maleiers als slaven te koop aangeboden werden, menschen die destijds nog groote handelsreizen maakten, ook naar Afrika - en dan gevaar liepen in handen van inlandsche sla-

1) $\mathrm{P}$ (ieter) de $\mathrm{M}$ (arees), Beschrijvinghe ... Gout Koninckrijck van Gunea, bew. S. P. L'Honoré Naber, Linschoten Ver. V, 1912.

2) Websters New International Dictionary. 
venhandelaars te vallen, misschien wel tengevolge van handelsdisputen 1).

Dat aan den menschenroof op de Westkust van Afrika reeds in het laatst der zeventiende eeuw Noordamerikaansche slavenhalers zich schuldig maakten, blijkt uit een petitie van 1694, in Maryland ingediend 2). Dit euvel gaf aanleiding tot représailles van de zijde der kustbevolking, gevangenneming van of moord op het personeel der schepen - en oefende een slechten invloed uit op de verhouding tusschen blanken en inboorlingen, derhalve op den handel. Dat ondanks maatregelen van de zijde der overheid menschenroof met de Noordamerikaansche slavenvaart bleef samengaan, ook na den kolonialen tijd, wordt aangetoond door een geval aan den Congo van 18073).

Wat betreft de slavenhalers uit Engeland werd de toestand aanmerkelijk slechter nadat in 1698 het monopolie der Royal Africa Company ingetrokken was; de vrije handelaars van Bristol en Liverpool hadden minder scrupules en waren minder streng tegenover hun varend personeel, dan de Company geweest was. Een act of Parliament van 1750 stelde straf (geldboete) op het bemachtigen van negers in Afrika door geweld, bedrog of verraad 4). Vermeld wordt dat geen verbetering intrad.

Ook het zich meester maken van menschen als pandelingen, wegens geldschuld, als gijzelaars, of als représaille tegen werkelijk of vermeend onrecht, van inboorlingen ondervonden, alles samen te vatten onder den naam panjaren (Port. penhorar) kwam vooral in de achttiende eeuw herhaaldelijk voor; de documenten betreffende de slavenvaart op de Amerika's staan er vol van.

Zelfs waren vrije negers, die zich op de Kust als matrozen verhuurden, aan boord van Amerikaansche en Engelsche schepen niet veilig; zij liepen gevaar aan den overkant van den oceaan als slaven verkocht te worden. Er kwam nog in 1795 een zoodanig geval ter kennis van den gouverneur van Sierra Leone ${ }^{5}$ ).

Nederlandsche slavenhalers schijnen zich aan de hooger gesignaleerde misbruiken niet schuldig gemaakt te hebben; ook kwam het uiterst zelden voor dat onze slavenschepen op de Kust door de inboorlingen werden aangevallen, of dat op den overtocht

1) Doc. ... Slave Trade ..., zie vroeger, Vol. II, eight. cent., document No. 161.

2) Als boven, Vol. IV, Border Col. and South. Col., doc. No. 8 .

3) Als boven, doc. No. 379 .

4) Als boven, Vol. II, eight. cent., doc. No. 217.

s) Als boven, Vol. III, New England and the Middle Col., doc. No. 78 
de slaven aan het muiten sloegen. Wel is het een gezagvoerder van een Nederlandsch schip geweest die eens een Afrikaan naar Europa overbracht, den bekenden Capitein, die hier te lande tot predikant opgeleid werd en later naar zijn geboorteland terugkeerde, waar hij evenwel niet aan hooge verwachtingen bleek te kunnen voldoen ${ }^{1}$ ).

In den aanvang der achttiende eeuw begonnen negers naar Afrika terug te keeren, uit Amerika en Europa, die vrijwillig of onvrijwillig hun land verlaten hadden, aanzienlijken en eenvoudigen, al dan niet na zich in hun ballingsoorden wegens ontvoering beklaagd te hebben. De Afrikaansche ,prinsen”, die in 1721 naar de Voltarivier terugkeerden ${ }^{2}$ ) zullen wel vrijwillig een bezoek aan Engeland gebracht hebben; de zoon van den ,Koning” van Popo, die omstreeks denzelfden tijd door een Engelschen slavenhaler, die zich bedrogen achtte, aan boord gevangen was gehouden, werd in vrijheid gesteld toen schadevergoeding verleend was en ontkwam dus aan een onvrijwillige zeereis ${ }^{3}$ ).

Een „factor" van de Royal Africa Company geraakte in een negeroorlog in Dahomey in gevangenschap; de Koning van dat land zond hem naar Engeland terug, als boodschapper en onder beding dat hij zou wederkeeren. Met hem reisde mede een andere gevangene van den Koning, een jongen, Tom genaamd, die Engelsch sprak en al lang met den Engelschen handel op de kust te maken gehad had. Deze Tom ging met zijn blanken meester eerst naar Barbados en later naar Maryland; in 1731 verschijnen beiden aan het Engelsche Hof en bezoeken in Londen den schouwburg. De negerjongen werd Oroonoko genoemd; het is echter mogelijk dat hij in de betreffende verhalen verward wordt met een anderen jeugdigen Afrikaan. Er wordt immers ook verteld, dat in 1731 een schip van de Kust vertrok naar Maryland, met een lading slaven, onder welke zich de zoon bevond van een hoogepriester; de jongeling zou de gevangene geweest zijn van een negervorst en door zijn eigen volk niet kunnen zijn vrijgekocht, omdat het schip te vlug vertrok. Enkele jaren later was deze Afrikaan terug aan de Westkust; hij was een jaar lang slaaf geweest in Maryland en daar goed behandeld. Hij was Mohammedaan en had een Arabischen brief naar Engeland weten te zenden, be-

1) Prof. Dr A. Eekhof, i.h. Ned. Archief v. Kerkgesch., n.s. XIII, 138, 209.

2) Doc. ... Slave Trade ..., zie vroeger, Vol. II, eight. cent., doc. 132.

3) Als boven, doc. 161 . 
stemd voor zijn vader. De brief kwam door een samenloop van omstandigheden in Engeland in handen van Kolonel James Oglethorpe, ,deputy governor" van de Royal Africa Company, die toen een reis naar Georgia voorbereidde, waar een Engelsche slavenlooze kolonie gesticht is. Oglethorpe liet den jongen, Job ben Solomon genaamd, een Jalof van Gambia, koopen en naar Engeland sturen. Job kwam aldaar in aanraking met Sir Hans Sloane M. D., den beroemden geleerde, reiziger en verzamelaar, die hem inschriften van Arabische penningen liet vertalen. Ook werd Job aan het Hof ontvangen; hij genoot echter geen goede gezondheid en keerde spoedig naar Gambia terug, vanwaar hij nog een brief schreef aan een Engelschen schrijfmeester. Het verhaal van zijn leven verscheen in 1734 te Londen in druk 1).

Een minder bekend geworden Mohammedaansche Afrikaan die als slaaf naar Amerika gevoerd werd, heeft toch ook zijn biograaf gevonden 2). De zucht van Franschen en Engelschen, hun Afrikaansche belangen te bevorderen, leidde er toe dat inlandsche vorsten uitgenoodigd werden hun zoons reizen naar Europa te laten maken; in 1749 vertoefden twee Afrikaansche ",prinsen" te Londen, die overal ontvangen werden en die de opvoering bijwoonden van Aphra Behn's R o y a l S l a v e als tooneelstuk 3).

Ik trof nog een andere merkwaardige Afrikaansche figuur in de achttiende-eeuwsche Amerikaansche geschiedenis aan, Gustavus Vassa. Deze zou als kind in Afrika gestolen zijn en aan een slavenhaler verkocht; hij werd in 1765 in South Carolina met een slavenschip aangevoerd, maar heeft ook op Barbados, in Virginia en te Philadelphia geleefd. In 1791 publiceerde hij zijn levensgeschiedenis 4).

Mungo Park, van wiens reizen in 1795-1797 in 1813 te New York het relaas verscheen, vertelde dat in zijn tijd de opkoopers in het Afrikaansche binnenland zich liefst van negers voorzagen die van kind af slaven geweest waren, zoodat er op het einde der achttiende eeuw weinig stof meer geweest zal zijn voor romantische verhalen aangaande onrechtmatige wegvoeringen. Toch trof deze geneesheer onder een lading van 130 koppen van Gambia en Gooree nog 25 personen aan die waarschijnlijk vroeger vrij

1) Doc. ... Slave Trade ..., zie vroeger, Vol. II, eight. cent., docum. Nos. $161,167,175,176,197,393$.

2) American Historical Review XXX, 787

3) Doc. ... Slave Trade ..., zie vroeger, Vol. II, eight. cent., doc. No. 220.

4) Als boven, Vol. IV, The Border Col. and the South. Col., doc. No.281. 
geweest waren; de meesten konden wat Arabisch schrijven en negen waren krijgsgevangenen uit een godsdienstoorlog 1).

Zijn er in den loop der tijden af en toe negers als slaven naar Amerika gevoerd die volgens Afrikaansche opvattingen geen slaven behoorden te zijn, het is ook voorgekomen dat zwarten die als slaven scheep gingen, als vrijen in de nieuwe wereld aankwamen. $\mathrm{Al}$ vroeg in de zeventiende eeuw moet het gebeurd zijn, dat slavenschepen dicht in de buurt der Caraibische Zee schipbreuk leden, dan wel de onvrijwillige passagiers zich in het gezicht van land van het schip meester wisten te maken. Het bekendste geval is dat hetwelk het aanzijn gegeven heeft aan de zwarte Caraiben op Saint Vincent.

Een Fransch reiziger, die in den aanvang van 1793 genoemd eiland bezocht, werd aldaar door een zwarten Caraib ontvangen, die op zijn Europeesch leefde, Engelsch sprak en op Saint Lucia en Martinique handel dreef. De eigenlijke hoofdman echter, die er slaven op na hield, was een bespottelijke kerel, die in een Fransche officiersuniform rondliep, hem geschonken als belooning voor tegen de Engelschen bedreven wandaden tijdens den Amerikaanschen vrijheidsoorlog. De zwarte Caraiben van Saint Vincent waren destijds nog heidenen; zij zouden enkele jaren later in opstand komen tegen het Engelsche gezag, welk oproer eindigde met hun deportatie naar het eilandje Roatan, in de golf van Honduras. In 1675 zou een slavenschip op het eilandje Bequia, iets ten zuiden van S. Vincent, schipbreuk geleden en de slaven zouden zich op laatstgenoemd eiland gered hebben. De negers onderwierpen de Caraibische inboorlingen, dan wel deze laatsten maakten zich van de negers meester - en uit de vermenging ontstonden de zwarte Caraiben, vertelt onze Franschman 2). Het verhaal behoeft niet ongeloofwaardig te zijn en het negertype der z.g. Caraiben op andere Westindische eilanden, op Dominica b.v., kan op dezelfde wijze, doch ook wel door vermenging van Indiaansche inboorlingen met in slavernij levende Afrikanen, ontstaan zijn, terwijl er ook rekening mede gehouden moet worden dat de blanken gedurende een paar eeuwen Afrikaansche en Indiaansche slaven naast elkander gehouden hebben. Ten slotte moet nog opgemerkt worden, dat de indertijd op Saint Vincent

1) Doc. ... Slave Trade ..., zie vroeger, Vol. II, eight. cent., doc. No. 292.

2) J. J. Dauxion Lavaysse, Voyage aux Isles de Trinidad, de Tabago, de la Marguerite, et dans diverses parties de Vénézuéla, Paris 1812, zesde hoofdstuk.

West-Indische Gids XXVI 
onderworpen en naar Roatan gedeporteerde opstandelingen in het algemeen Caribs genoemd werden en dat er nog in later tijd op S. Vincent ,yellow Caribs” en ,,black Caribs” leefden.

Nieuwsberichten van 1750 vermeldden dat er dat jaar op een slavenschip voor West Indië een muiterij uitbrak, welke eindigde met het vermoorden der blanken. De negers lieten echter een stuurman in het leven en dwongen dezen het schip naar Deseada te brengen, een der Leeward Islands, waarvan de muiters meenden dat het niet door blanken bewoond was. Wat er verder gebeurde is niet duidelijk 1). Dat de slaven het schip z.g. ,,afliepen” kwam herhaaldelijk yoor - in de Nederlandsche slavenvaart echter uiterst zelden - en niet alleen op de Afrikaansche kust, waar men lang moest vertoeven voordat de "lading” compleet was, maar ook wel op het einde van den overtocht, dicht bij de Westindische eilanden. In dit laatste geval was de aanvoerder der muiters meestal een neger die met de blanken omgegaan had en hun taal sprak.

Een volkomen mislukte revolte, bewerkt door een neger die door een Franschen slavenhaler op de Afrikaansche kust door bedrog zou zijn medegevoerd, in het begin der negentiende eeuw, moet beschreven zijn in de $\mathrm{Revue} d \mathrm{e} \mathrm{Paris}$, onder den titel Tamanco. Het verhaal is even fantastisch als Aphra Behn's Royal Slave, doch de afloop was een geheel andere, want de held zou door een Engelsch oorlogsschip gered zijn en de rest van zijn leven op Jamaica als slaaf hebben doorgebracht 2). Tamanco had wel niet de pretensie een prins te zijn - hij was in zijn eigen land handelaar in slaven geweest - maar hij wordt toch wel als een interessant personage beschreven. Wellicht echter zijn de blanken in West Indië nog lang toegankelijk gebleven voor verhalen van slaven, die hoog opgaven van hun Afrikaansche voornaamheid. Dr. Benjamins haalde reeds twee Nederlandsche schrijvers aan die blijkbaar onder den indruk gekomen waren van zulke verhalen; een achttiende eeuwsche Duitsche schrijver vertelt ons dat op de toenmalige Deensche Antillen slaven werden aangetroffen die hoogmoedig optraden en beweerden in Afrika personen van aanzien geweest te zijn ${ }^{3}$ ). Amsterdam December 1942.

1) Doc. ... Slave Trade ..., zie vroeger, Vol. II, eight. cent., doc. No. 218.

2) Le Navigateur, Journal des naufrages et des autres evénemens nautiques, Havre Oct. 1829 , bl. 65 e.v.

3) C. G. A. Oldendorps Geschichte der Mission der evangelischen Brüder auf den caraibischen Inseln S. Thomas, S. Croix und S. Jan, Barby 1777, bl. 371-372. 